\title{
Soil Minerals Serving as Source of Arsenic in Alluvial Aquifers of Holocene: A Case Study from Indus Delta, Sindh, Pakistan
}

\author{
Adnan Khan ${ }^{1 *}$, Suhail Anjum², Viqar Husain ${ }^{1}$ \\ ${ }^{1}$ Department of Geology, University of Karachi, Karachi, Pakistan \\ ${ }^{2}$ Department of Geology FUUAST, Karachi, Pakistan \\ * Corresponding author : adkhan@uok.edu.pk \\ Telp.:+92-300-3635848 \\ Received: Oct 1, 2016; Accepted: Nov 20, 2019. \\ DOI: 10.25299/jgeet.2019.4.4.3077 \\ Abstract: \\ Groundwater arsenic contamination is recently reported in the alluvial aquifers of Indus deltaic plain. Since the source of arsenic is believed \\ to be natural as widely reported in other deltaic aquifers of same age (Holocene), it is imperative to evaluate the soil characteristics for identifying \\ the sources of arsenic and its mobilization mechanism. For this purpose, 49 soil samples were collected from near aquifer sites in all three talukas \\ of Tando Muhammad Khan district. Visual analysis revealed that soil is light grey in color with fine texture ranging from silt to silty-clay. The X- \\ ray diffraction study reveals the occurrence of quartz, mica and clay minerals in all collected soil samples. Plagioclase feldspar is second \\ dominant mineral group in the order of albite (calcian) >albite >albite (disordered) $=$ anorthite $>$ anorthite (sodian) $=$ anorthite $($ disordered). \\ Calcite is major carbonate mineral which is detected in 40 out of total 49 soil samples. The occurrence of other occasional minerals includes \\ amesite, nitro-calcite, rutile and zinnwaldite. The frequency of micaceous minerals in collected samples is in the order of clinochlore> \\ polylithionite > Biotite > phlogopite > muscovite. Polylithionite is found in about half of the total soil samples, where most of the aquifers contain \\ arsenic $>20 \mu \mathrm{g} / \mathrm{L}$ (Khan, 2014). Phlogopite is observed in seven soil samples which are also associated with clinochlore. On the other hand, \\ biotite is found in 14 sediment samples collected from Tando Muhammad Khan and Bhulri Shah Karim talukas and muscovite occurs in three \\ soil samples of Tando Muhammad Khan taluka. It can be concluded from present study that fine-grained phyllosilicates have strong affinity for \\ arsenic retention. These sediments are important source of arsenic Indus delta and other deltaic plains of the world.
}

Keywords: Arsenic, sediments, alluvial aquifers, Holocene, Indus delta, Pakistan.

\section{Introduction}

Arsenic is widespread contaminant in the environment and its adverse health effects are a global concer(WHO, 2010). There are two major sources of arsenic which includes weathering of minerals (Bhumbla and Keefer, 1994; Yan-Chu, 1994; Mandal and Suzuki, 2002; Foley and Ayuso, 2008; Mailloux et al., 2009) and anthropogenic activities like mining activities, industrial wastes and agricultural in puts (Chilvers and Peterson, 1987). Chronic application of pesticides and herbicides also results in substantial accumulation in soils (Hiltbold, et al., 1974)Mineralogy is one of the important research approaches for disclosing the mechanism of environmental contamination (Akai et al., 2004; Akai and Anawar, 2013). The geogenic As is of serious concern in countries like Bangladesh, India, and Vietnam. High concentration of As in soil and water has also been noted in developed countries, e.g., US (Peryea and Creger, 1994)and South Australia and Tasmania (Merry, et al., 1983) It is widely believed that high concentration of arsenic (As) is mainly confined to the sedimentary aquifers of Holocene age (Bhattacharya, et al., 1997; Ishiga, 2000; Anawar et al., 2002, 2003)High levels of arsenic in groundwater mainly result from natural contamination(Chowdhury, et al., 1999; Acharyya et al., 2000; Nicksonet al., 2000; McArthur and Ravenscroft, 2000; Anawar et al., 2002; Polizzotto and Harvey, 2005; Rabbani et al., 2017).Various theories have been put forward regarding the modes of arsenic release, ranging from oxidative or reductive degradation of arsenic-bearing solids to competitive ligand displacement by phosphate(Chakrapani et al., 1995; Bhattacharya, et al., 1997; Acharyya et al., 2000;
Nickson et al.,2000; McArthur and Ravenscroft, 2000).

Major As minerals occurring in nature are niccolite, realgar, orpiment, cobaltite, arsenopyrite, tennatite, enargite, arsenolite, claudetite, scorodite, annabergite, hoernesite, haematolite, conichalcite and pharmacosiderite (Smedley and Kinniburgh, 2002)These minerals originate in hydrothermal veins, hot springs, secondary minerals deposited oxidation products of associated As minerals. These mineral deposits are typically associated with orogeny where volcanic activity and metamorphism are quite common. Hence, the occurrence of As in Himalayan river basin is rational. All the rivers deposit fine to very fine textured sediments in deltaic region due to low energy and very high suspended load. These fine sediments are mainly comprised of minerals like quartz, feldspar and biotite which contains As concentration in the range of $0.4-1.3,0.1-2.1$ and $1.4 \mathrm{mg} / \mathrm{kg}$ respectively (Garlick and Wedepohl, 1969). On the other hand, calcite and dolomite contains Arsenic in the range of $1-8$ and $<3 \mathrm{mg} / \mathrm{kg}$ respectively.

Beside arsenic speciation and toxicity in the soil, several studies have documented relatively higher As concentration in the soil as compared to the aquifer materials (Onken and Hossner, 1995; Swartz et al., 2004; Polizzotto et al., 2006).It is due to the fact that arsenic compounds are absorbed strongly onto soil, and therefore transported only over short distances in surface and groundwater (Manning and Goldberg, 1997).Solid phase As and Fe becomes more reduced with depth (0.5-3.6 m) in the soil and released via redox cycling in surface soils/sediments into the sandy aquifer (Polizzotto et al., 2008). 
Keeping in view these facts, it is likely that the constituent minerals in the alluvial deposits of Tando Muhammad Khan district (part of Indus deltaic flood plain)are probable source of As-enriched groundwater, similar to other highly As enriched groundwaters of (Anawar et al., 2003; Polizzotto et al., 2006) West Bengal (Nath et al., 2008; Hery et al., 2010; Nath et al., 2011)Vietnam(Berg et al., 2008) China (Xie et al., 2009) and Spain (Garcia-Sanchez et al., 2005).Substantial work has been carried out by various workers on the groundwater of Tando Muhammad Khan to explain the arsenic contamination(Husain et al., 2012; Khan et al., 2014, 2017) However, sediment characteristics have not yet been studied to explain the possible source/host of arsenic responsible for high arsenic groundwater in study area. Therefore, present study is aimed at characterizing the near aquifer site sediments in terms of mineral composition and chemical characteristics to link with the hydrogeochemical characters of the corresponding groundwater in order to complete the picture of arsenic release mechanism in study area.

\section{Material and Methods}

\subsection{Study area}

Indus Basin is topographically a plain area, characteristically devoid of any well-defined natural surface and subsurface drainage (Qureshi et al., 2008)It covers an area of $2600 \mathrm{sq} . \mathrm{km}$ covering the whole Hyderabad Division comprising of Tando Mohammad Khan, Tando Allayar and Matiari districts. Geology of Tando Muhammad Khan district is very simple where the Holocene fine sediments cover the surface and Indus River flows on the western margin of the basin (Fig.1). Surface soil comprises fine textured sediments dominated by silt and clay with subordinate sand (Kazmi, 1984). The entire study area is covered with marsh peat, micaceous silt and clay units similar to Bangladesh (Shamsudduha et al., 2008).

\subsubsection{Quaternary Sediments}

Quaternary sediments of Late Holocene have carpeted the surface geology of study area that are brought by the Indus River (Kazmi, 1984; Mehmood et al., 2009). Deposition of such young sediments is mainly controlled by orogenic movement of Himalayas which incepted in the Early Pleistocene time (Gill, 1952). This phase of orogeny was the strongest of all stages where major structural and tectonic events took place in terms of folding, faulting and uplift. This was the time when thick deposition of sediments in all parts of Himalayan basin occurred including deltaic part of Indus basin. (Acharyya, et al., 2000; Polizzotto et al., 2006; Alizai et al., 2012).

Interestingly, Holocene aquifers are the host of high arsenic groundwater worldwide.(Acharya, 2005). Similar is true about alluvial deposits of Tando Muhammad Khan district and adjoining areas where more than $600 \mathrm{ppb}$ arsenic is reported in shallow alluvial aquifers (Husain et al., 2012). These flood plain deposits of study area have been classified in Table 1 out of which two are described below due to the fact that only these two comprises the surface geology of study district.

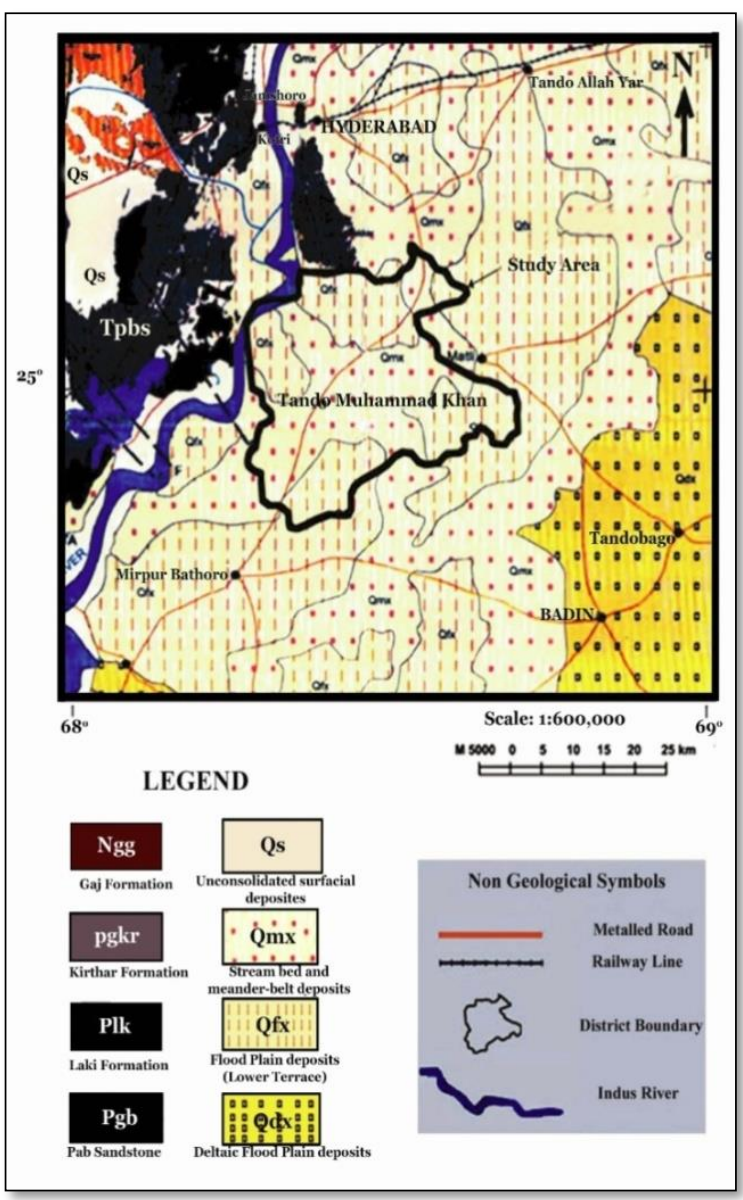

Fig. 1 Geological map of Tando Muhammad Khan district and adjoining areas.

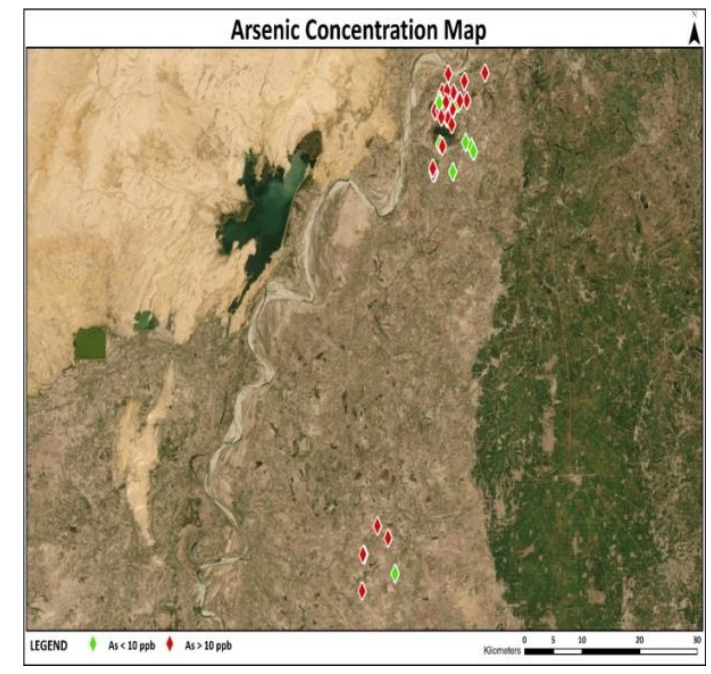

Fig. 2 Map showing the arsenic distribution in groundwater of study area.

\subsubsection{Surficial Deposits of Alluvium}

The surficial alluvial deposits in study and adjoining areas consists of fine sand, silt and clay transported and deposited by the streams resulting in the formation of cultivable land. 


\subsubsection{Extinct Streams Deposits}

Extinct Streams Deposits carve the surface geology of Tando Muhammad Khan district (Table 1). These sediments form the flood plain deposits overlain by the river channel and meander belt deposits. The sediments of lower Indus flood plain comprise of greenish grey to grey clay and silt followed by fine sand. Sporadically these deposits are interlayered with some sticky, black and calcareous clay. These sediments can be characteristically seen in shallow depressions formed by the chocked estuaries and surrounded by salt at some places, interlayered with sticky black calcareous clay. These are characterized by long shallow depressions formed by choked estuaries and occupied by salt deposits.

The meander belt and stream bed deposits show imprints of older meander belts traces. These deposits are the admixture of poorly sorted sediments of fine sand with subordinate silty clay. These sediments are directly overlying the deltaic alluvium (Akhtar et al., 2012).

Table 1 Stratigraphic Units of Holocene In Tando Muhammad Khan District and Adjoining Areas (after (Akhtar et al., 2012).

\begin{tabular}{|c|c|c|c|c|}
\hline Period & Epoch & Deposit / Formation & Sub Units & Lithological Description \\
\hline \multirow[t]{5}{*}{ Quartenary } & Holocene & Stream bed deposits & Floodplain deposits & $\begin{array}{l}\text { Low lying areas along river, frequently } \\
\text { inundated during high floods. These are flat } \\
\text { and relatively even surfaces }\end{array}$ \\
\hline & & & $\begin{array}{l}\text { Stream Bed and Meander belt } \\
\text { deposits }\end{array}$ & $\begin{array}{l}\text { Deposits characterized by river meanders, } \\
\text { cut off, oxbow lakes, abandoned channels } \\
\text { numerous point bars, swales, and sand } \\
\text { ridges. }\end{array}$ \\
\hline & & $\begin{array}{l}\text { Surficial } \\
\text { deposits }\end{array}$ & $\begin{array}{l}\text { Unconsolidated surficial } \\
\text { deposits }\end{array}$ & $\begin{array}{l}\text { Deposit consist of sand, silt and clayey } \\
\text { material brought by streams }\end{array}$ \\
\hline & & of extinct & $\begin{array}{l}\text { Stream bed and meander belt } \\
\text { deposits }\end{array}$ & $\begin{array}{l}\text { Poorly sorted fine to medium grained sand, } \\
\text { silt, and least aboundant clay }\end{array}$ \\
\hline & & & $\begin{array}{l}\text { Floodplain deposits } \text { (lower } \\
\text { Terraces) }\end{array}$ & $\begin{array}{l}\text { Consist of greenish gray to gray silt and clay } \\
\text { with subordinate fine sand, occasionally } \\
\text { intercalated with sticky black clay }\end{array}$ \\
\hline
\end{tabular}

\subsection{Soil Sampling for Mineralogical Analysis}

Forty-nine representative soil samples (about 0.3 meters depth) near aquifer sites were taken from various parts of study area. Sample location was marked on the map using Global Positioning System. The soil samples were collected using hand shovel in the plastic bags. The physical properties (i.e. color, texture) of the collected samples were also documented in the field. The samples were air dried for about 2 days at room temperature and subsequently oven dried at $105^{\circ} \mathrm{C}$. The dried sample was ground to very fine mesh and sieved through $2 \mathrm{~mm}$ screen to eliminate the coarse particles and other deleterious material.

Table 2. Minerals identified in the soil collected from various localities of Tando Muhammad Khan Taluka

\begin{tabular}{|c|c|c|c|c|c|c|}
\hline \multirow{2}{*}{ S.No. } & \multirow{2}{*}{ Sample Code } & \multirow[b]{2}{*}{ Union Council } & \multicolumn{2}{|c|}{ Coordinates } & \multirow{2}{*}{ Arsenic $\mu \mathrm{g} / \mathrm{L}$} & \multirow{2}{*}{ Identified Minerals } \\
\hline & & & Lat. ${ }^{\circ} \mathbf{N}$ & Long. ${ }^{\circ} \mathbf{E}$ & & \\
\hline 1 & TMK-1 & UC-1 & 250753 & 683201 & 80 & Quartz, Calcite (Magnician), Albite (Calcian), Clinochlore, Biotite \\
\hline 2 & TMK-2 & UC-2 & 250743 & 683209 & 400 & Quartz, Albite (Calcian), Dolomite, Clinochlore, Muscovite \\
\hline 4 & TMK-5 & UC-2 & 250715 & 683145 & 40 & Quartz, Calcite (Magnician), Clinochlore, Biotite \\
\hline 5 & TMK-6 & $\mathrm{UC}-1$ & 250719 & 683234 & 5 & Quartz, , Clinochlore, Albite (Calcian), Biotite \\
\hline 8 & TMK-16 & UC-1 & 250750 & 683316 & 400 & Quartz, Albite (Calcian), Calcite (Magnician), Clinochlore, Biotite \\
\hline 9 & TMK-18 & UC-1 & 250740 & 683338 & 150 & Quartz, Anorthite, Polylithionite, Clinochlore \\
\hline 10 & TMK-19 & TandoSaindad & 250926 & 683433 & 150 & Quartz, Albite, Calcite, Chlorite (Serpentinite), Muscovite \\
\hline 11 & TMK-23 & TandoSaindad & 251138 & 683352 & 300 & Quartz, Calcite (Magnician), Albite (Calcian), Biotite, Clinochlore \\
\hline 12 & TMK-24 & TandoSaindad & 251152 & 683925 & 30 & Quartz, Calcite (Magnician), Anorthite, Phlogopite, Clinochlore \\
\hline 16 & TMK-71 & Lakhat & 250018 & 683109 & 250 & Quartz, Calcite, Albite, Dolomite, Clinochlore, Biotite \\
\hline 17 & TMK-86 & Lakhat & 250018 & 683422 & 0 & Quartz, Calcite, Albite (Calcian), Phlogopite, Clinochlore \\
\hline 18 & TMK-87 & UC-1 & 250743 & 683351 & 5 & Quartz, Polylithionite, Calcite (magnician), Albite (calcian). Clinochlore \\
\hline 19 & TMK-88 & TandoSaindad & 250737 & 683418 & 200 & Quartz, Albite (calcian), Phlogopite, Nitro calcite, Clinochlore \\
\hline 20 & TMK-89 & TandoSaindad & 250811 & 683341 & 80 & Quartz, Polylithionite, Calcite (magnician), Clinochlore, Albite \\
\hline 21 & TMK-90 & TandoSaindad & 250834 & 683326 & 20 & Quartz, Polylithionite, Calcite, Anorthite (sodian) \\
\hline 22 & TMK-91 & TandoSaindad & 250839 & 683343 & 10 & Quartz, Polylithionite, Calcite (magnician), Albite (disordered), Clinochlore \\
\hline 23 & TMK-92 & TandoSaindad & 250946 & 683331 & 60 & Quartz, Polylithionite, Albite (calcian), Calcite, Clinochlore \\
\hline 24 & TMK-93 & TandoSaindad & 250838 & 683220 & 60 & Quartz, , Albite (calcian), Calcite, Polylithionite \\
\hline 25 & TMK-95 & UC-1 & 250806 & 683214 & 0 & Quartz, Polylithionite, Albite (calcian)., Calcite, Clinochlore \\
\hline 26 & TMK-97 & UC-1 & 250721 & 683311 & 60 & Quartz, Polylithionite, Albite (calcian). Clinochlore \\
\hline
\end{tabular}




\begin{tabular}{ccccccl}
28 & TMK-99 & UC-1 & 250627 & 683349 & 80 & Quartz, Polylithionite, Calcite (magnician), Albite (calcian) \\
29 & TMK-100 & UC-2 & 250557 & 683405 & 100 & Quartz, Calcite (magnician), Anorthite (disordered), biotite \\
30 & TMK-108 & TandoSaindad & 250808 & 683503 & 0 & Quartz, Calcite (magnician), Anorthite (sodian), muscovite \\
31 & TMK-110 & TandoSaindad & 250835 & 683640 & 30 & Quartz, Polylithionite, Anorthite (disordered), Clinochlore \\
32 & TMK-112 & Lakhat & 250831 & 683534 & 100 & Quartz, Calcite (magnician), Albite (disordered), zinnwaldite, Clinochlore \\
33 & TMK-127 & Lakhat & 250334 & 683219 & 5 & Quartz, Polylithionite Calcite (magnician), Albite (disordered), zinnwaldite, Clinochlore \\
34 & TMK-129 & Lakhat & 250309 & 683259 & 30 & Quartz, Calcite(magnician), Albite (calcian), Polylithionite, Clinochlore \\
35 & TMK-135 & Lakhat & 250008 & 683134 & 60 & Quartz, Calcite, Anorthite, Biotite, Clinochlore \\
36 & TMK-136 & Lakhat & 250004 & 683117 & 80 & Quartz, Polylithionite, Calcite(magnician), Albite (calcian), Clinochlore \\
37 & TMK-138 & Lakhat & 250056 & 683111 & 40 & Quartz, Polylithionite, Calcite(magnician), Albite (calcian), Clinochlore \\
38 & TMK-141 & UC-1 & 250815 & 683317 & 20 & Quartz, Polylithionite, Calcite(magnician), Albite (calcian), Clinochlore \\
39 & TMK-145 & UC-2 & 250644 & 683244 & 80 & Quartz, Polylithionite, Calcite(magnician), Albite (calcian) \\
40 & TMK-153 & TandoSaindad & 251056 & 683603 & 60 & Quartz, Albite (calcian), Calcite \\
\hline
\end{tabular}

Sample weighing 100 grams $(n=49)$ was sent to the laboratory for XRD analysis for mineral identification.

\subsection{Sediment Analysis}

Soil samples were analyzed by a widely used technique of X-ray diffraction (Bish and Post, 1989; Moore and Reynolds, 1997) to determine the crystalline phase of the same. All the samples were scanned through a range of $2 \theta$ angles. Variable orientation of the powdered soil provided all possible diffraction directions. The d-spacing of each peak was subsequently obtained by the conversion of diffraction peaks. The conversion of peaks into d-spacing indicated a specific mineral due to the fact that every mineral manifest a distinct set of differing d-spacing. At the end, the d-spacing was compared with standard reference pattern.

\section{Results and Discussion}

\subsection{Mineralogical Characterization of near Aquifer}

\section{Sediments}

Table 3. Minerals identified in the soil collected from various localities of Bhulri Shah Karim Taluka.

\begin{tabular}{cccccll}
\hline \multirow{2}{*}{ S. No. } & \multirow{2}{*}{ Sample Code } & \multirow{2}{*}{ Union Council } & \multicolumn{2}{c}{ Coordinates } & \multirow{2}{*}{ Arsenic $\boldsymbol{\mu g} / \mathbf{L}$} & \\
& & & Lat. ${ }^{\circ} \mathbf{N}$ & Long. ${ }^{\circ} \mathbf{E}$ & & Identified Minerals \\
\hline 41 & TMK-39 & Mullakatyar & 250633 & 681808 & 0 & Quartz, Calcite, Albite (Calcian), Phlogopite, Clinochlore \\
42 & TMK-58 & Bhulri Shah Karim & 245204 & 682003 & 150 & Quartz, Calcite (Magnician), Biotite, Clinochlore, Albite (Calcian) \\
43 & TMK-66 & Allayar Turk & 245814 & 682410 & 200 & Quartz, Calcite, Biotite, Clinochlore, Albite (Calcian) \\
44 & TMK-118 & Mullakatyar & 245954 & 682244 & 10 & Quartz, Albite (calcian), Polylithionite, Clinochlore \\
45 & TMK-121 & JhannanSoomro & 245622 & 682036 & 60 & Quartz, Calcite (Magnician), Albite (Calcian), Polylithionite \\
46 & TMK-122 & JhannanSoomro & 245625 & 682017 & 80 & Quartz, Calcite, Albite (Calcian), biotite \\
\hline
\end{tabular}

Table 4. Minerals identified in the soil collected from various localities of Taluka Tando Ghulam Hyder.

\begin{tabular}{|c|c|c|c|c|c|c|}
\hline \multirow{2}{*}{$\begin{array}{l}\text { S. } \\
\text { No. }\end{array}$} & \multirow{2}{*}{ Sample No. } & \multirow{2}{*}{$\begin{array}{c}\text { Union } \\
\text { Council }\end{array}$} & \multicolumn{2}{|c|}{ Coordinates } & \multirow{2}{*}{ Arsenic $\mu \mathrm{g} / \mathrm{L}$} & \multirow{2}{*}{ Identified Minerals } \\
\hline & & & Lat. ${ }^{\circ} \mathbf{N}$ & Long. ${ }^{\circ} \mathbf{E}$ & & \\
\hline 47 & TMK-105 & Nazarpur & 250354 & 683622 & 300 & Quartz, Calcite,polylithionite, Albite (calcian), clinochlore \\
\hline 48 & TMK-106 & Nazarpur & 250302 & 683712 & 100 & Quartz, Calcite (magnician), Albite (calcian), polylithionite, clinochlore \\
\hline 49 & TMK-107 & Nazarpur & 250252 & 683745 & 50 & Quartz, polylithionite, Calcite (magnician), Albite (calcian), clinochlore \\
\hline
\end{tabular}

Quartz occurred in all the collected samples while plagioclase feldspar is second frequent mineral group in the order of albite (calcian) >albite>albite (disordered) $=$ anorthite $>$ anorthite $($ sodian $)=$ anorthite $($ disordered $)$. Calcite is another dominate member among carbonate minerals which is detected in 40 out of total 49 soil samples. On the other hand, micaceous minerals span between frequency range of 3-38 samples in fine textured soil (silty-clay). These platy minerals varied in the order of clinochlore $>$ polylithionite $>$ biotite $>$ phlogopite $>$ muscovite in the study area. Other rare minerals include amesite, nitrocalcite, rutile and zinnwaldite.

These minerals occurring in the sediments of Tando Muhammad Khan district are mainly derived from western Himalayas during Holocene Period (Giosan et al., 2006). The
Forty-nine representative soil samples were collected from near well sites in three talukas of Tando Muhammad Khan district, where arsenic in groundwater occurs in the range of 10-500 $\mu \mathrm{g} / \mathrm{L}$ (Fig. 2). In Tando Muhammad Khand taluka, arsenic varies between $10-500 \mu \mathrm{g} / \mathrm{L}$ in groundwater where about $80 \%$ of the wells have arsenic above WHO recommended value $(10 \mu \mathrm{g} / \mathrm{L})$ for drinking purpose. On the other hand, 4 out of 6 wells in Bhulri Shah Karim taluka shows arsenic content in the range of $10-200 \mu \mathrm{g} / \mathrm{L}$. Likewise, all 3 samples of water from Bhulri Shah Karim exceed the WHO guideline value (50-300 $\mu \mathrm{g} / \mathrm{L})$. Soil samples were collected from near these sites where groundwater exhibited the variable content of arsenic. Mineralogical study was carried out using XRD technique which revealed the occurrence of quartz, mica and clay minerals as major components in all collected samples (Table $1-3)$. 
sediments of Bengal basin which is also drained by Ganges, Fe oxides are precipitated mostly at the edges relative to basal Brahmaputra and Meghna rivers from Himalayas. Clinochlore surfaces (Murakami et al., 2003). .Nath et al., (2008) shows that seems to play a vital role in elevated concentration of arsenic and top soils are enriched in arsenic with low Fe-oxyhydroxides that iron via desorption process in the groundwater of Tando can be compared with the findings of Métral et al. (2008). Muhammad Khan district, where its occurrence is more Chakraborty et al. (2007)explained that $\mathrm{Fe}(\mathrm{OH})_{3}$ is presumed to prevalent than biotite and other phyllosilicates (Table 2-4). The be derived from the weathering of mica, iron sulfide and other occurrence of clinochlore in 36 soil samples from all three primary Fe-bearing minerals in the Holocene aquifer sediments talukas of Tando Muhammad Khan district can have substitution where highest arsenic concentrations are reported. of $\mathrm{Fe}$ in the cationic sites in the form of $\mathrm{Fe}^{+2}$ and /or $\mathrm{Fe}^{+3}$, where a wide range of arsenic $(5-500 \mu \mathrm{g} / \mathrm{L})$ occurs in the groundwater(Mosaferi et al., 2014)

\subsubsection{Polylithionite}

About half of the collected samples contain polylithionite mineral where most of the aquifers contain arsenic $>20 \mu \mathrm{g} / \mathrm{L}$ (Table 3). Polylithionite is also reported in the sediments of Chandpur district, Bangladesh where almost all the shallow hand tube wells water is highly arsenic contaminated (Ahmed et al., 2008). This mineral is one of the lithium rich mica which is not a better-known mica mineral but its high occurrence in the sediments of Indus delta clued about its less chemical reactivity and abundance in the source area. The occurrence of objectionable arsenic concentration in the aquifers overlying the polylithionitic soil suggests a strong affinity with arsenic with this mineral.

\subsubsection{Biotite-Phlogopite}

Biotite occurred in the fourteen collected sediment samples from Tando Muhammad Khan and Bhulri Shah Karim talukas and muscovite occurs in three soil samples of Union Council-2 and Tando Saindad. The role of phyllosilicates to serve as Asfixing phase has been pointed out in previous studies (Foster et al., 2000; Breit et al., 2001; (Pal et al., 2002; Ahmed, 2004). Biotite shows more reactive site for arsenic adsorption as compared to muscovite. Likewise, silty mica as compared to sand size provide more effective site for arsenic adsorption. There is an effective role of $\mathrm{pH}$ on arsenic adsorption on micas. Studies carried out by Chakraborty et al., (2007) and Pal et al., (2002) revealed that silt-sized biotite retained 214 $\mathrm{mg} / \mathrm{kg}$ of arsenate in circum neutral $\mathrm{pH}$ (6.5-7.5). conversely, silt sized.

It can be inferred from these studies that flood plain soil is more prone to retain arsenic as compared to aquifer sediments. Similar pattern is observed in the study area where surface sediments comprises micaceous minerals (muscovite biotite and phlogopite) which are thought to be the good absorbents of metals (Ansari, 1997; sing et al, 2005; Datta and Subramanian, 1997). These minerals absorb As into surface $\mathrm{Fe}(\mathrm{III})$ and As rich precipitates (Charlet et al, 2002).

Dissolution and alterations in biotite and muscovite within acidic to alkaline $\mathrm{pH}$ region have been investigated by various workers (Kalinowski and Sachweda, 1996; Malmstrom et al., 1996; Turpault and Trotignon, 1994; Samson et al, 2005). Interestingly, biotite provides more reactive surface as compared to muscovite (Farquhar et al, 1997). Moreover, edges of freshly cleaved muscovite surface are more reactive site than crystal face (Zhang and Bailey, 1998; Johnsson et al, 1992). However, the accumulation of arsenic both on edges and to lesser extent on the basal pinacoid of mica is reported by Charlet et al, (2005).

Beside iron sulfides and other primary Fe-bearing minerals, iron (hydro) oxides are pressured to be derived from weathering of micas(Polizzotto et al., 2006). It was observed by Chakraborty et al., (2007)in an experiment that biotite dissolution starts from the crystal's edges inward. Moreover, secondary minerals such as

Phlogopite is fourth important micaceous mineral reported in the soil of study area where it is reported in seven soil samples. It is a yellow, greenish, or reddish-brown member of the mica family of phyllosilicates. Phlogopite is also known as magnesium mica which is the magnesium end member of the biotite solid solution series, with the chemical formula $\mathrm{KMg}_{3} \mathrm{AlSi}_{3} \mathrm{O}_{10}(\mathrm{~F}, \mathrm{OH})_{2}$.

\subsubsection{Chlorite}

The chlorites are a group of phyllosilicate minerals. Chlorite is major detrital mineral transported through rivers which have been originated from Himalayas (Chakrapani et al., 1995)This mineral is the product of physical weathering which prevails in cold climate (Bockheim, 1982; Campbell and Claridge, 1982)Since the sediments have been sourced from Himalayan region (alpine glacier) and transported through Indus River to reach the deltaic setting, the occurrence of chlorite in high proportion is rational. Contrary to this, kaolinite (indicator of intense chemical weathering) was not detected in any soil sample (Table 2a-c). It implies that monsoon climate was weakened gradually since mid-Holocene and physical disintegration of rocks dominated over chemical weathering (Alizai et al., 2012)A study carried out by (Rasool et al., 2016) in upper reaches of Indus basin (Punjab plain) determined the occurrence of high arsenic groundwater in aerobic aquifers where sediments showed linear relationship to XRD intensity of chlorite. A study carried out in Bengal delta revealed that grey soft clay constitutes chlorite beside other minerals(Pal and Mukherjee, 2009)

\subsubsection{Calcite}

Calcite is reported to occur in 40 sediment samples $(n=49)$ which is expected to be derived by the weathering of limestone beds of Eocene age which are cropping out in Ganja Hills located on the western bank of River Indus near study area. Moreover, calcitemagnesiun occurs more frequently as compared to calcite which is attributed to one of the important magnesium sources in the aquifers of Tando Muhammad Khan district. Nitro calcite is found in a sample collected from an irrigated well in agricultural land of Tando Saindad Union Council, where groundwater contained $200 \mu \mathrm{g} / \mathrm{L}$ arsenic. Although dolomite is reported only in two samples of UC-2 and Lakhat but a good correction has been observed with aqueous arsenic where groundwater contains 400 and 250 $\mu \mathrm{g} / \mathrm{L}$ arsenic respectively.

Calcite is the major carbonate mineral in study area which suggests its proximal source due to the fact that carbonate minerals are less resistant against chemical weathering (Garrison, 1981)As a result, the transportation of calcite as residual grain from Himalayas to the Indus deltaic plain is not possible. Hence, the source of calcite is weathering of Laki limestone occurring in the proximity of Indus river in study area. The calcite contains $1-8 \mathrm{mg} / \mathrm{kg}$ of arsenic in it whereas dolomite host As $<3 \mathrm{mg} / \mathrm{kg}$ (Boyle and Jonasson, 1973). Likewise, limestone hosts about $2.6 \mathrm{mg} / \mathrm{kg}$ of arsenic (Baur and Onishi, 1969). Hence, these carbonate minerals are serving as potential minerals to adsorb As in calcareous soils, 
where calcite plays a vital role in retention and solubility of arsenic (Mehmood et al., 2009).

\section{Conclusion}

Present study has revealed the occurrence of large number of Phyllosilicates which are also reported from Bengal delta plain in the fine fractions of the soil. These minerals included clinochlore, polylithionite, biotite and phlogopite as major platy minerals. These fine silicates are serving as main source of arsenic in the deltaic setting either by sorbing the arsenic or hosting this metalloid into their structure. Upon prevalence of anoxia caused by bacteria mediated organic matter decay, these minerals release their sorbed or structural arsenic into the water which reaches the aquifer depth upon infiltration. Calcite is major carbonate mineral which is serving as arsenic host. Further studies are required to assess the chemistry of soil and aquifer sediments to better explain the source and mechanism of arsenic mobilization in shallow alluvial aquifers of the deltaic system.

\section{Acknowledgement}

Present study was carried out with the financial support of Higher Education Commission (HEC) on project titled "Geochemical and Geo-microbiological Investigations of Groundwater Arsenic Contamination in District Tando Muhammad Khan, Sindh: Impact of Human Health and Mitigation Options". Authors are highly indebted to Geoscience Advanced Research laboratory, Islamabad for providing the facility to analyze the sediment samples.

\section{References}

Acharyya, S. (2005) 'Arsenic levels in groundwater from Quaternary alluvium in the Ganga Plain and the Bengal Basin, Indian subcontinent: insights into influence of stratigraphy', Gondwana Research, 8(1), pp. 55-66. Available https://www.sciencedirect.com/science/article/pii/S13429 37X05702628 (Accessed: 15 March 2019).

Acharyya, S. K. et al. (2000) 'Arsenic toxicity of groundwater in parts of the Bengal basin in India and Bangladesh: the role of Quaternary stratigraphy and Holocene sea-level fluctuation', Environmental Geology, 39(10), pp. 11271137. doi: $10.1007 / \mathrm{s} 002540000107$.

Acharyya, S., Lahiri, S. and Raymahashay, B. (2000) 'Arsenic toxicity of groundwater in parts of the Bengal basin in India and Bangladesh: the role of Quaternary stratigraphy and Holocene sea-level fluctuation', Applied Geochemistry, 15(4), pp. 55-56. Available at: https://idp.springer.com/authorize/casa?redirect_uri=https ://link.springer.com/article/10.1007/s002540000107\&cas a_token=0s9iPOrE85cAAAAA:bsIGT0vxkB4GSU5mjG nZ7YoMeFScX58_ABR7IIavhORcGOXy9jOSQw_Tnpy-m72_HEHe3P43vqTBoljjQ (Accessed: 4 March 2019).

Ahmed, K. (2004) Management of the groundwater arsenic disaster in Bangladesh, In Natural Arsenic in Groundwater: Proceedings of the Pre-Congress Workshop" Natural Arsenic in Groundwater", 32nd International Geological Congress, Florence, Italy, . Available https://books.google.com.pk/books?hl=en\&lr=\&id=MBn YPI-

$601 \mathrm{gC} \&$ oi $=$ fnd $\&$ pg $=$ PA283\&dq=+awareness + campaigns ,+and+the+wise+use+of+the+water+sources+that+are+lo w+in+arsenic $+($ Ahmed+et+al., +2004$)+\& o t s=$ G15JSfiNs o\&sig=HH4KoZhor-RFzVc_quriYoQKFVM (Accessed: 13 March 2019).

Akai, J. et al. (2004) 'Mineralogical and geomicrobiological investigations on groundwater arsenic enrichment in Bangladesh', Applied geochemistry. Available at: https://www.sciencedirect.com/science/article/pii/S08832 9270300177x (Accessed: 21 January 2019).

Akai, J. and Anawar, H. (2013) 'Mineralogical approach in elucidation of contamination mechanism for toxic trace elements in the environment: special reference to arsenic contamination in', Physics and Chemistry of the Earth, Parts $\quad A / B / C$. Available at: https://www.sciencedirect.com/science/article/pii/S14747 06513000375 (Accessed: 21 January 2019).

Akhtar, M. et al. (2012) 'Geological Map of Sindh, Pakistan'.

Alizai, A. et al. (2012) 'Clay mineral variations in Holocene terrestrial sediments from the Indus Basin', Quaternary Research , 77, pp. 368-381. Available at: https://www.cambridge.org/core/journals/quaternaryresearch/article/clay-mineral-variations-in-holoceneterrestrial-sediments-from-the-indusbasin/41319345A0C182CFECA961A565F5ABE9 (Accessed: 4 January 2019).

Anawar, H. et al. (2002) 'Arsenic poisoning in groundwater: health risk and geochemical sources in Bangladesh', Environment International. Available at: https://www.sciencedirect.com/science/article/pii/S01604 12001001167 (Accessed: 21 January 2019).

Anawar, H. et al. (2003) 'Geochemical occurrence of arsenic in groundwater of Bangladesh: sources and mobilization processes', Journal of Geochemical. Available at: https://www.sciencedirect.com/science/article/pii/S03756 7420200273X (Accessed: 21 January 2019).

Berg, M. et al. (2008) 'Hydrological and sedimentary controls leading to arsenic contamination of groundwater in the Hanoi area, Vietnam: the impact of iron-arsenic ratios, peat, river bank', Chemical geology, 249(1-2), pp. 91112. Available at: https://www.sciencedirect.com/science/article/pii/S00092 54107004949 (Accessed: 5 March 2019).

Bhattacharya, P., Chatterjee, D. and Jacks, G. (1997) 'Occurrence of Arsenic-contaminatedGroundwater in Alluvial Aquifers from Delta Plains, Eastern India: Options for Safe Drinking Water Supply', International Journal of Water Resources Development, 13(1), pp. 7992. doi: 10.1080/07900629749944.

Bhumbla, D. and Keefer, R. (1994) 'Arsenic in the environment'. Available at: https://scholar.google.com/scholar?hl=en\&as_sdt=0\%2C $5 \& q=$ Bhumbla + and + Keefer $+1994 \& b \operatorname{tnG}=($ Accessed: 28 February 2019).

Bockheim, J. (1982) 'Properties of a chronosequence of ultraxerous soils in the Trans-Antarctic Mountains', Geoderma, 28(3-4), pp. 239-255. Available at: https://www.sciencedirect.com/science/article/pii/001670 6182900052 (Accessed: 13 March 2019).

Boyle, R. and Jonasson, I. (1973) 'The geochemistry of arsenic and its use as an indicator element in geochemical prospecting', Journal of Geochemical Exploration, 2(3), 
pp.

251-296

Available

at:

https://www.sciencedirect.com/science/article/pii/037567 4273900034 (Accessed: 13 March 2019).

Campbell, I. and Claridge, G. (1982) 'The influence of moisture on the development of soils of the cold deserts of Antarctica', Geoderma , 28(3-4), pp. 221-238. Available at: https://www.sciencedirect.com/science/article/pii/001670 6182900040 (Accessed: 13 March 2019).

Chakraborty, S. et al. (2007) 'Adsorption of arsenite and arsenate onto muscovite and biotite mica', Journal of Colloid and Interface Science, 309(2), pp. 392-401. Available

at: https://www.sciencedirect.com/science/article/pii/S00219 79706009234 (Accessed: 4 January 2019).

Chakrapani, G. J. et al. (1995) 'Size characteristics and mineralogy of suspended sediments of the Ganges river, India', Environmental Geology, 25(3), pp. 192-196. doi: 10.1007/BF00768548.

Chilvers, D. and Peterson, P. (1987) 'Global cycling of arsenic', Lead, mercury, cadmium and arsenic in the environment, , pp. 279-301.

Chowdhury, T., Basu, G. and Mandal, B. (1999) 'Arsenic poisoning in the Ganges delta', Nature. Available at: https://www.sid.ir/En/Journal/ViewPaper.aspx?ID=32739 6 (Accessed: 21 January 2019).

Foley, N. and Ayuso, R. (2008) 'Mineral sources and transport pathways for arsenic release in a coastal watershed, USA', Geochemistry: Exploration, Environment, Analysis, , 8(1), pp. 59-75. Available at: https://pubs.geoscienceworld.org/geea/articleabstract/8/1/59/269328 (Accessed: 28 February 2019).

Garcia-Sanchez, A., Moyano, A. and Mayorga, P. (2005) 'High arsenic contents in groundwater of central Spain', Environmental geology, 47(6), pp. 847-854. Available at: https://idp.springer.com/authorize/casa?redirect_uri=https ://link.springer.com/article/10.1007/s00254-004-1216$8 \&$ casa token $=\mathrm{A} 4 \mathrm{k} 2 \mathrm{Hr}-$

4o1AAAAAA:otc8LZstjQttj107ffnndmP3MBy1OvfzPRpg_gmt0tgo3JiIX4rQHcKX3yrbCGjlbwYY5QveKPJ lND3pA (Accessed: 5 March 2019).

Garlick, G. and Wedepohl, K. (1969) Handbook of geochemistry. Available at https://scholar.google.com.pk/scholar?hl=en\&as_sdt=0\% $2 \mathrm{C} 5 \& \mathrm{q}=+\mathrm{Baur} \% 2 \mathrm{C}+\mathrm{WH} \% 2 \mathrm{C}+\mathrm{Onishi} \% 2 \mathrm{C}+\mathrm{BMH} \% 2 \mathrm{C}+$ $1969 \% 2 \mathrm{C}+$ Arsenic $\% 2 \mathrm{C}+\mathrm{In} \% 3 \mathrm{~A}+$ Wedepohl $\% 2 \mathrm{C}+\mathrm{KH}+$ $\% 28 \mathrm{Ed} . \% 29 \% 2 \mathrm{C}+$ Handbook+of+Geochemistry\%2C+Sp ringer-

Verlag\%2C+Berlin.+Belzile $\% 2 \mathrm{C}+\mathrm{N} . \% 2 \mathrm{C}+1988 \% 2 \mathrm{C}+\mathrm{T}$ he+fate+of+arsenic+in+sediment (Accessed: 15 March 2019).

Garrison, R. (1981) 'Diagenesis of oceanic carbonate sediments: a review of the DSDP perspective'. Available at:

http://archives.datapages.com/data/sepm_sp/SP32/Diagen esis_of_Oceanic_Carbonate.pdf (Accessed: 13 March 2019).

Giosan, L. et al. (2006) 'On the control of climate-and humanmodulated fluvial sediment delivery on river delta development: The Indus', AGU Fall Meeting. Available at:
http://adsabs.harvard.edu/abs/2006AGUFMOS14A..04G (Accessed: 21 January 2019).

HÉRY, M. et al. (2010) 'Arsenic release and attenuation in low organic carbon aquifer sediments from West Bengal', Geobiology, 8(2), pp. 155-168. doi: 10.1111/j.1472-4669.2010.00233.x.

Hiltbold, A. E., Hajek, B. F. and Buchanan, G. A. (1974) 'Distribution of arsenic in soil profiles after repeated applications of MSMA', Weed Science, 22(3), pp. 272275. Available at: https://www.cambridge.org/core/journals/weedscience/article/distribution-of-arsenic-in-soil-profilesafter-repeated-applications-ofmsma/EC8D51B1E38CD6FA6430185E095F4034 (Accessed: 28 February 2019).

Husain, V. et al. (2012) 'Natural arsenic in groundwater of Indus delta in the province of Sindh, Pakistan', Understanding the Geological and Medical Interface of Arsenic, As 2012 - 4th International Congress: Arsenic in the Environment, (November 2014). Available at: http://www.scopus.com/inward/record.url?eid=2-s2.084864877231\&partnerID=MN8TOARS.

Ishiga, H. (2000) 'Geological constraints on arsenic contamination of groundwater in Bangladesh', Arsenic Contamination Forum. Available at: https://ci.nii.ac.jp/naid/10012147397/ (Accessed: 21 January 2019).

Kazmi, A. (1984) 'Geology of the Indus delta', Marine geology and oceanography of Arabian Sea and coastal Pakistan, pp. 71-84.

Khan, A. et al. (2014) 'Arsenic contamination status in the Holocene alluvial aquifers of Indus Deltaic Flood Plain: a case study of Tando Ghulam Hyder Taluka, Sindh, Pakistan', Econ-Environ-Geol.Org, 5(2), pp. 1-10. Available at: http://www.econ-environgeol.org/pdf/jul2014/01.pdf.

Khan, A. et al. (2017) 'Groundwater arsenic contamination in shallow alluvial aquifers of Bhulri Shah Karim taluka, Tando Muhammad Khan', International Journal of Ground Sediment \& Water Vol., 5(2), pp. 217-244. Available at: http://ijgsw.comze.com.

Mailloux, B. et al. (2009) 'Microbial mineral weathering for nutrient acquisition releases arsenic', Appl. Environ. Microbiol, 75(8), pp. 2558-2565. Available at: https://aem.asm.org/content/75/8/2558.short (Accessed: 28 February 2019).

Mandal, B. and Suzuki, K. (2002) 'Arsenic round the world: a review', Talanta, 58(1), pp. 201-235. Available at: https://www.sciencedirect.com/science/article/pii/S00399 14002002680 (Accessed: 28 February 2019).

Manning, B. A. and Goldberg, S. (1997) 'Adsorption and Stability of Arsenic(III) at the Clay Mineral-Water Interface', Environmental Science \& Technology, 31(7), pp. 2005-2011. doi: 10.1021/es9608104.

Mehmood, A. et al. (2009) 'Mechanisms of arsenic adsorption in calcareous soils', J Agric Biol Sci, 1(1), pp. 59-65. Available at: http://citeseerx.ist.psu.edu/viewdoc/download?doi=10.1.1 .725.5556\&rep=rep1\&type=pdf (Accessed: 4 January 2019). 
Merry, R., Tiller, K. and Alston, A. (1983) 'Accumulation of copper, lead and arsenic in some Australian orchard soils', Australian orchard soils. Soil Research, 21(4), pp. 549-61. Available at http://www.publish.csiro.au/sr/SR9830549 (Accessed: 4 March 2019).

Métral, J. et al. (2008) 'Comparison of dissolved and particulate arsenic distributions in shallow aquifers of Chakdaha, India, and Araihazar, Bangladesh', Geochemical Transactions, 9(1), p. 1. doi: 10.1186/14674866-9-1.

Mosaferi, M. et al. (2014) 'Removal of Arsenic (III, V) from aqueous solution by nanoscale zero-valent iron stabilized with starch and carboxymethyl cellulose', Journal of Environmental Health Science and Engineering, 12(1), p. 74. doi: 10.1186/2052-336X-12-74.

Murakami, T. et al. (2003) 'Biotite dissolution processes and mechanisms in the laboratory and in nature: Early stage weathering environment and vermiculitization', American Mineralogist, 88(2-3), pp. 377-386. Available at: https://pubs.geoscienceworld.org/msa/ammin/articleabstract/88/2-3/377/43924 (Accessed: 13 March 2019).

Nath, B. et al. (2008) 'Hydrochemistry of Arsenic-Enriched Aquifer from Rural West Bengal, India: A Study of the Arsenic Exposure and Mitigation Option', Water, Air, and Soil Pollution, 190(1-4), pp. 95-113. doi: 10.1007/s11270-007-9583-x.

Nath, B. et al. (2008) 'Mobility of arsenic in West Bengal aquifers conducting low and high groundwater arsenic. Part I: Comparative hydrochemical and hydrogeological characteristics', Applied Geochemistry, 23(5), pp. $977-$ 995. Available https://www.sciencedirect.com/science/article/pii/S08832 92708000498 (Accessed: 4 March 2019).

Nath, B. et al. (2009) 'Mobility of arsenic in the sub-surface environment: An integrated hydrogeochemical study and sorption model of the sandy aquifer materials', ournal of Hydrology, 364(3-4), pp. 236-248. Available at: https://www.sciencedirect.com/science/article/pii/S00221 69408005386 (Accessed: 15 March 2019).

Nath, B. et al. (2011) 'Geochemical characterization of arsenic-affected alluvial aquifers of the Bengal Delta (West Bengal and Bangladesh) and Chianan Plains (SW Taiwan)', Applied Geochemistry, 26(5), pp. 705-713. Available

https://www.sciencedirect.com/science/article/pii/S08832 92711000412 (Accessed: 15 March 2019).

Nickson, R., McArthur, J. and Ravenscroft, P. (2000) 'Mechanism of arsenic release to groundwater, Bangladesh and West Bengal', Applied Geochemistry. Available at: https://www.sciencedirect.com/science/article/pii/S08832 92799000864 (Accessed: 21 January 2019).

Onken, B. and Hossner, L. (1995) 'Plant uptake and determination of arsenic species in soil solution under flooded conditions', Journal of Environmental Quality, 24(2), pp. 373-381. Available at: https://dl.sciencesocieties.org/publications/jeq/abstracts/2 4/2/JEQ0240020373 (Accessed: 4 March 2019).

Organization, W. H. (2010) 'Drinking water quality in the South-East Asia region'. Available at: https://apps.who.int/iris/bitstream/handle/10665/204999/ B4470.pdf (Accessed: 28 February 2019).

Pal, T. et al. (2002) 'Arsenic pollution in groundwater of West Bengal, India-An insight into the problem by subsurface sediment analysis', Gondwana Research, 5(2), pp. 501512. Available https://www.sciencedirect.com/science/article/pii/S13429 37X05707383 (Accessed: 13 March 2019).

Pal, T. and Mukherjee, P. K. (2009) 'Study of subsurface geology in locating arsenic-free groundwater in Bengal delta, West Bengal, India', Environmental Geology, 56(6), pp. 1211-1225. doi: 10.1007/s00254-008-1221-4.

Peryea, F. J. and Creger, T. L. (1994) 'Vertical distribution of lead and arsenic in soils contaminated with lead arsenate pesticide residues', HortScience, 78(3-4), pp. 297-306. doi: 10.1007/BF00483038.

Polizzotto, M. et al. (2006) 'Solid-phases and desorption processes of arsenic within Bangladesh sediments', Chemical Geology. Available at: https://www.sciencedirect.com/science/article/pii/S00092 54106000349 (Accessed: 21 January 2019).

Polizzotto, M. et al. (2008) 'Near-surface wetland sediments as a source of arsenic release to ground water in Asia', Nature. Available at: https://www.nature.com/articles/nature07093 (Accessed: 21 January 2019).

Polizzotto, M. and Harvey, C. (2005) 'Processes conducive to the release and transport of arsenic into aquifers of Bangladesh', National Academy of Sciences. Available at: http://www.pnas.org/content/102/52/18819.short (Accessed: 21 January 2019).

Qureshi, A. et al. (2008) 'Managing salinity and waterlogging in the Indus Basin of Pakistan', Agriculture water, 95(1), pp. 1-10. Available at: https://www.sciencedirect.com/science/article/pii/S03783 77407002429 (Accessed: 5 March 2019).

Rabbani, U. et al. (2017) 'Risk assessment for arseniccontaminated groundwater along River Indus in Pakistan', Environmental Geochemistry and Health. Springer Netherlands, 39(1), pp. 179-190. doi: 10.1007/s10653-016-9818-0.

Rasool, A. et al. (2016) 'Elevated levels of arsenic and trace metals in drinking water of Tehsil Mailsi, Punjab, Pakistan', Journal of Geochemical Exploration, 169, pp. 89-99. Available

at: https://www.sciencedirect.com/science/article/pii/S03756 7421630156X (Accessed: 13 March 2019).

Seddique, A. et al. (2008) 'Arsenic release from biotite into a Holocene groundwater aquifer in Bangladesh', Applied Geochemistry, 23(8), pp. 2236-2248. Available at: https://www.sciencedirect.com/science/article/pii/S08832 92708001297 (Accessed: 15 March 2019).

Shamsudduha, M. et al. (2008) 'Quaternary stratigraphy, sediment characteristics and geochemistry of arseniccontaminated alluvial aquifers in the GangesBrahmaputra floodplain in central', Journal of Contaminant Hydrology, 99(1-4), pp. 112-136. Available https://www.sciencedirect.com/science/article/pii/S01697 7220800051X (Accessed: 5 March 2019). 
Smedley, P. and Kinniburgh, D. (2002) 'A review of the source, behaviour and distribution of arsenic in natura waters', Applied Geochemistry, 17(5), pp. 517-568. Available at:

https://www.sciencedirect.com/science/article/pii/S08832 92702000185 (Accessed: 4 March 2019).

Swartz, C. et al. (2004) 'Mobility of arsenic in a Bangladesh aquifer: Inferences from geochemical profiles, leaching data, and mineralogical characterization', Geochimica et Cosmochimica Acta, , 68(22), pp. 4539-4557. Available at:

https://www.sciencedirect.com/science/article/pii/S00167 03704003692 (Accessed: 4 March 2019).
Xie, X. et al. (2009) 'Geochemistry of redox-sensitive elements and sulfur isotopes in the high arsenic groundwater system of Datong Basin, China', Science of the total environment, 407(12), pp. 3823-3835. Available at:

https://www.sciencedirect.com/science/article/pii/S00489 69709000813 (Accessed: 5 March 2019).

Yan-Chu, H. (1994) 'Arsenic distribution in soils. In "Arsenic in the Environment, Part I: Cycling and Characterization"(JO Nriagu, Ed.)'.

(c) (†) () 2016 Journal of Geoscience, Engineering, Environment and Technology. All rights reserved. This is an open access article distributed under the terms of the CC BY-SA License (http://creativecommons.org/licenses/by-sa/4.0/). 